\title{
STUDI RESIDU ANTIBIOTIK DAGING BROILER YANG BEREDAR DI PASAR TRADISIONAL KOTA KENDARI
}

\author{
Saniwanti ${ }^{1}$, Nuraini ${ }^{2}$, Dian Agustina ${ }^{2}$ \\ ${ }^{1)}$ Alumnus Fakultas Peternakan UHO \\ ${ }^{2)}$ Staf Pengajar Fakultas Peternakan UHO \\ *e-mail : andimurlinatasse@gmail.com
}

\begin{abstract}
ABSTRAK
Salah satu produk asal ternak yang memiliki angka konsumsi yang cukup tinggi berasal dari jenis unggas yaitu ayam broiler sehingga memerlukan penambahan aditif pakan berupa antibiotik kedalam ransum untuk meningkatkan pertumbuhan dan daya tahan tubuh ayam broiler. Akibat dari penggunaan antibiotik tersebut sehingga ditemukan residu antibiotik dalam pangan asal hewan khususnya ayam broiler. Penelitian ini bertujuan untuk mengetahui ada tidaknya residu antibiotik golongan tetrasiklin, makrolida dan aminoglikosida dalam daging ayam broiler yang beredar dipasar tradisional Kota Kendari. Penelitian ini dilaksanakan dengan cara pengambilan sampel dari 3 pasar tradisional Kota Kendari dan sebanyak 5 sampel tiap pasar serta dianalisa Laboratorium Unit Mikrobiologi, Jurusan Biologi, Fakultas MIPA, Universitas Haluoleo. Pengambilan sampel dilakukan dengan metode purposive sampling, hasilnya dianalisis secara deskriptif. Pengujian residu antibiotika menggunakan metode Bioassay. Hasil penelitian menunjukkan bahwa 10 sampel ayam broiler mengandung residu antibiotik golongan tetrasiklin, 15 sampel golongan makrolida dan 9 sampel golongan aminoglikosida.
\end{abstract}

Kata kunci: Residu, antibiotik, daging ayam broiler.

\begin{abstract}
One of livestock base product that has enough figure of consumption comes from fowl is broilers so that it needs to add feed addictive such as antibiotic into ration in order to improve growth and body endurance of broilers. The effect of that antibiotic usage is found in food that comes from animal particularly broilers. The objective of this study is to find out whether or not the antibiotic residue tetracycline, macrolide, and aminoglicoside in the flesh of broilers that circulates in traditional market Kendari. This study is conducted by taking sample from 3 traditional markets in Kendari and 5 samples each market and analyzed by Microbiology Unit Laboratory, Biology Department, MIPA faculty, Haluoleo University. The taking sample process is done by using purposive sampling method, its result is analyzed descriptively. The trial of antibiotic residue uses Bioassay method. The result of the study showed that 10 broilers samples had tetracycline antibiotic residue, 15 samples had macrolide, and 9 samples have aminoglicoside.
\end{abstract}

Key words: residue, antibiotic, broilers flesh

*) Corresponding authors

\section{PENDAHULUAN}

Pangan asal ternak $r$ sangat
dibutuhkan manusia sebagai sumber
protein. Protein hewani menjadi sangat
penting karena mengandung asam-asam
amino yang mendekati susunan asam
amino yang dibutuhkan manusia sehingga

akan lebih mudah dicerna dan lebih efisien pemanfaatannya. Namun demikian, pangan asal ternak akan menjadi tidak berguna dan membahayakan kesehatan manusia apabila tidak aman untuk dikonsumsi. Oleh karena itu, keamanan pangan asal ternak merupakan persyaratan mutlak (Winarno, 1996). 
Pentingnya keamanan pangan ini sejalan dengan semakin baiknya kesadaran masyarakat akan pangan asal ternak yang berkualitas, artinya selain nilai gizinya tinggi, produk tersebut aman dan bebas dari cemaran mikroba, bahan kimia atau cemaran yang dapat mengganggu kesehatan. Keamanan pangan asal ternak selalu merupakan isu aktual yang perlu mendapat perhatian dari produsen, konsumen, dan para penentu kebijakan, karena selain berkaitan dengan kesehatan masyarakat juga mempunyai dampak ekonomi pada perdagangan lokal, regional maupun global.

Salah satu produk asal ternak yang memiliki angka konsumsi yang cukup tinggi berasal dari jenis unggas karena selain mudah diperoleh, cepat pertumbuhannya, dan harganya juga lebih terjangkau dibanding dengan jenis ternak besar. Data konsumsi ayam broiler kota Kendari menunjukkan angka 0,1696 $\mathrm{kg} / \mathrm{kapita} / \mathrm{tahun}$ dan angka 0,0324 $\mathrm{kg} / \mathrm{kapita} /$ tahun untuk rata-rata konsumsi ayam broiler Sulawesi Tenggara secara umum (Dinas Pertanian Sultra, 2010). Data yang terhitung tinggi ini secara tidak langsung memberikan kesadaran pada masyarakat akan keamanan pangan yang dikonsumsinya.

Perkembangan genetik ayam broiler semakin pesat, sehingga ayam broiler tidak lagi dipotong pada umur 35 hari tetapi menjadi lebih cepat yaitu 29 hari. Pertumbuhan yang cepat tersebut diikuti oleh menurunnya daya tahan tubuh sehingga diperlukan penambahan aditif pakan ke dalam ransum untuk meningkatkan pertumbuhan dan daya tahan tubuh ayam broiler (Keirs et al., 2002)

Ditemukannya residu antibiotik dalam makanan asal hewan erat kaitannya dengan penggunaan antibiotik untuk pencegahan dan pengobatan penyakit serta penggunaan sebagai aditif pakan. Hal yang merisaukan adalah adanya pencampuran bahan baku aditif pakan dalam ramuan yang dilakukan sendiri oleh peternak yang kurang dapat dijamin ketepatan takarannya sehingga dapat menyebabkan terpaparnya residu tersebut pada pangan asal ternak khususnya ayam broiler (Anonimous, 1994).

Pelarangan penggunaan antibiotik di luar negeri (Eropa) sudah lama diterapkan karena dikhawatirkan adanya residu pada produk-produk ternak seperti daging, telur serta susu. U.S Agriculture Department melakukan pemeriksaan terhadap daging, unggas, dan produk olahan telur, jarang ditemukan residu pada level yang aman. Selain itu, penggunaan antibiotik pada ternak berlebihan mengakibatkan resistensi kuman pada tubuh manusia apabila mengkonsumsi produk-produk Peternakan (Anonimous, 2010).

\section{MATERI DAN METODE}

\section{A. Lokasi dan Waktu}

Pengambilan sampel dilakukan pada pasar-pasar tradisional Kota Kendari. Penelitian dan Analisis sampel dilaksanakan di Laboratorium Unit Mikrobiologi, Jurusan Biologi, Fakultas MIPA, Universitas Haluoleo, Kendari, pada bulan Desember 2011 sampai dengan Februari 2012.

\section{B. Materi Penelitian}

Materi penelitian menggunakan karkas ayam broiler sebanyak 15 ekor diperoleh dari 3 pasar tradisional di Wilayah Kota Kendari yaitu Pasar Mandonga, Pasar Kota, dan Pasar Bonggoea dengan berat rata-rata $1,7 \mathrm{~kg}$. Setiap pasar dipilih 5 pedagang dan masing-masing pedagang diperoleh 1 sampel karkas ayam.

Alat-alat yang digunakan dalam pengambilan sampel adalah wadah tupperware, kantong plastik dan pisau. Alat yang digunakan pada pengujian terhadap residu antibiotik di laboratorium 
yaitu erlenmeyer, pipet volumetrik, vorteks, sentrifuga, penangas air, pengaduk magnet, autoklaf, alat pembeku, aliran laminar, inkubator, cawan petri dan kertas cakram. Sedangkan bahan yang digunakan adalah medium nutrien agar, dapar fosfat, spora bakteri Bacillus cereus, Bacillus subtilis dan Micrococcus luteus.

\section{Prosedur Penelitian \\ 1. Penentuan Lokasi}

Penentuan lokasi berdasarkan survei awal lokasi penjualan karkas ayam broiler di setiap pasar tradisional di Kota Kendari dengan metode purposive sampling. Kriteria penentuan lokasi adalah pasar dengan jumlah pedagang karkas ayam lebih banyak dibanding pasar lainnya. Berdasarkan hasil survei awal ditetapkan Pasar Mandonga, Kota dan Bonggoea sebagai lokasi pengambilan sampel penelitian.

\section{Pengambilan Sampel}

Sampel karkas ayam broiler 15 ekor masing-masing diambil bagian paha kemudian disimpan dalam tupperware steril, kemudian dibawa ke laboratorium untuk dianalisa.

\section{Pengujian di Laboratorium}

Pengujian Laboratorium di lakukan untuk pemeriksaan mikrobiologis (residu tetrasiklin, aminoglikosida dan tetrasiklin) dengan metode bioassay. Metode tersebut diuraikan secara jelas sebagai berikut:

\section{Sterilisasi Alat dan Bahan}

Alat dan bahan yang digunakan terlebih dahulu disterilkan, dengan metode sterilisasi basah. Sterilisasi alat dan bahan menggunakan autoklaf bertekanan $1 \mathrm{~atm}$ $121^{\circ} \mathrm{C}$, selama 1 jam.

\section{Pengujian residu}

Sampel ditimbang sebanyak 10 gram, kemudian ditambahkan $20 \mathrm{ml}$ dapar fosfat $\mathrm{pH} \quad 7,0$ dan disentrifuga dengan kecepatan $3000 \mathrm{rpm}$ selama 10 menit, selanjutnya diambil supernatannya.
Media agar yang sudah ditambahkan kuman standar Bacillus cereus ATCC 1178 untuk golongan tetrasiklin, Bacillus subtilis ATCC 6633 untuk golongan Aminoglikosida, dan Micrococcus luteus ATCC 9341 untuk golongan makrolida lalu didiamkan sampai beku. Kertas cakram ditempelkan pada media dan ditambahkan $75 \mu$ l sampel pada setiap cawan petri $75 \mu l$ standar antibiotika sesuai dengan golongan antibiotika yang diuji, lalu diinkubasikan pada inkubator pada suhu $37^{\circ} \mathrm{C}$ selama $16-18$ jam. Diameter zona hambatan yang terbentuk di sekeliling sampel diukur dengan jangka sorong. Sampel dinyatakan positif mengandung residu antibiotika apabila zona hambatan yang terbentuk minimal $2 \mathrm{~mm}$ lebih besar dari diameter kertas cakram. Tahapan pengujian residu antibiotik dapat dilihat pada Gambar 3.

\section{Variabel Penelitian}

Variabel yang diamati pada penelitian ini adalah:

a. Residu antibiotik golongan Tetrasiklin

b. Residu antibiotik golongan Makrolida

c. Residuantibiotik golongan Aminoglikosida

Sampel diuji terhadap residu antibiotika secara kualitatif dengan teknik bioassay.

\section{E. Analisis Data}

Data yang diperoleh dihitung berdasarkan diameter zona hambat yang terbentuk dan selanjutnya dianalisis secara deskriptif.

\section{HASIL DAN PEMBAHASAN}

\section{A. Deteksi Residu Antibiotik Golongan Tetrasiklin}

Hasil deteksi residu antibiotik golongan Tertasiklin daging ayam broiler yang beredar di pasar tradisional Kota Kendari dapat dilihat pada Tabel 1 berikut. 
Tabel 1. Rataan Diameter Zona Hambat Pengujian Residu Antibiotik golongan Tetrasiklin pada Daging Ayam Broiler

\begin{tabular}{|c|c|c|c|c|}
\hline \multirow{2}{*}{ Jenis Antibiotik } & \multirow{2}{*}{ Sampel } & \multicolumn{3}{|c|}{ Lokasi } \\
\hline & & Pasar Kota & Pasar Mandonga & Pasar Bonggoeya \\
\hline \multirow{6}{*}{ Tetrasiklin } & & $\ldots \ldots \ldots$ & $\ldots \ldots \ldots(\mathrm{mm}) \ldots \ldots$ & \\
\hline & 1 & 4,5 & 0 & 8,0 \\
\hline & 2 & 7,5 & 0 & 7,0 \\
\hline & 3 & 9,0 & 0 & 4,5 \\
\hline & 4 & 17,5 & 0 & 5,5 \\
\hline & 5 & 9,0 & 0 & 6,0 \\
\hline Rata-rata & & 9,5 & 0 & 6,2 \\
\hline
\end{tabular}

- Diameter zona hambat $>2 \mathrm{~mm}$ dinyatakan sampel positif mengandung residu antibiotik

- Diameter zona hambat <13mm batas maksimum residu berdasarkan aturan SNI No. 01 - 6366-2000

Tabel 1 memperlihatkan bahwa dari 15 sampel daging ayam broiler yang berasal dari 3 pasar tradisional, 10 sampel positif mengandung residu antibiotik golongan tetrasiklin yaitu berasal dari pasar Kota dan pasar Bonggoea, sedangkan pasar Mandonga tidak terdapat satupun sampel yang positif mengandung residu antibiotik tetrasiklin.

Rataan diameter zona hambat sampel daging ayam broiler berasal dari pasar Kota yakni 9,5 mm, pasar Mandonga negatif dan pasar Bonggoea $6,2 \mathrm{~mm}$ artinya diameter zona hambat yang terbentuk masih di bawah batas maksimum residu yang ditetapkan SNI 01 - 6366 - 2000 yaitu maksimum $0,1 \mathrm{ppm}$ (diameter zona hambat $<13 \mathrm{~mm}$ ) sehingga masih aman dikonsumsi.

Hasil pengujian ini sejalan dengan penelitian Dewi et al., (2002) yang menemukan residu antibiotika golongan tetrasiklin di wilayah kabupaten Badung pada sampel produk asal ternak baik daging segar maupun daging olahan yang diambil di beberapa hotel, pasar tradisional dan rumah potong hewan (RPH).

Hasil pengujian antibiotik menemukan sedikitnya 10 sampel ayam dari 2 pasar tradisional yaitu pasar Kota dan Bonggoea positif mengandung residu antibiotik tetrasiklin kemungkinan disebabkan oleh pemberian antibiotik pada saat ayam masih dalam pemeliharaan dan dipotong sebelum waktu henti obat (withdrawaltime) berakhir sehingga antibiotik masih terakumulasi di daging ayam tersebut.

Kemungkinan lain adalah pakan komersial yang diberikan waktu pemeliharaan mengandung antibiotik. Menurut Bahri (2008) hampir semua pabrik pakan menambahkan senyawa obat berupa antibiotik ke dalam ransum jadi sebagai aditif pakan. Botsoglou et al., (2001) menambahkan antibiotik seperti tetrasiklin secara luas digunakan dalam dunia peternakan baik untuk pengobatan, pencegahan penyakit maupun sebagai tambahan dalam pakan yang mendorong pertumbuhan pada ternak.

Golongan tetrasiklin tidak termasuk dalam daftar aditif pakan yang diizinkan, namun harganya relatif murah dibandingkan antibiotika yang memang diperbolehkan untuk imbuhan, maka golongan tetrasiklin banyak digunakan sebagai aditif pakan (Murdiati et al., 1991)

Dari hasil pengujian antibiotik ditemukan 1 sampel yang sudah tidak aman dikonsumsi menurut SNI No. 01 6366 - 2000. Hal ini mungkin disebabkan oleh pemberian antibiotik di ambang batas pada ayam broiler saat pemeliharaan sebagaimana pendapat Anonimous (2010) setiap jenis antibiotik memiliki aturan pakai masing-masing tergantung cara kerja antibiotik tersebut, dan pemberian di JITRO VOL.2.NO.2.MEI 2015 
ambang batas akan meninggalkan residu antibiotik dalam tubuh ayam.

Sampel yang berasal dari pasar Mandonga tidak ditemukan residu antibiotik tetrasiklin kemungkinan karena ternak dipotong setelah masa henti obat dilewati atau peternak memberi pakan jagung tanpa konsentrat sebelum tiba waktu potong sehingga memungkinkan antibiotik yang dikonsumsi bersama pakan komersil selama pemeliharaan sudah dikeluarkan bersama feses.

Waktu henti obat hewan sangat bervariasi, bergantung pada: 1) jenis obat, 2) spesies hewan, 3) faktor genetik ternak,
4) iklim setempat, 5) cara pemberian, 6) dosis obat, 7) status kesehatan hewan, 8) produk ternak yang dihasilkan, 9) batas toleransi residu obat, dan 10) formulasi obat (Infovet, 2007).

\section{B. Deteksi Residu Antibiotik Golongan Makrolida}

Hasil deteksi residu antibiotik golongan Makrolida daging ayam broiler yang beredar di pasar tradisional Kota Kendari dapat dilihat pada Tabel 2.

Tabel 2. Rataan Diameter Zona Hambat Pengujian Residu Antibiotik golongan Makrolida pada Daging Ayam Broiler

\begin{tabular}{|c|c|c|c|c|}
\hline \multirow{2}{*}{ Jenis Antibiotik } & \multirow{2}{*}{ Sampel } & \multicolumn{3}{|c|}{ Lokasi } \\
\hline & & Pasar Kota & Pasar Mandonga & Pasar Bonggoeya \\
\hline \multirow{6}{*}{ Makrolida } & & & $\ldots \ldots \ldots \ldots(\mathrm{mm})$. & $\ldots \ldots \ldots \ldots \ldots \ldots$ \\
\hline & 1 & 6,0 & 6,5 & 2,5 \\
\hline & 2 & 8,0 & 4,5 & 3,5 \\
\hline & 3 & 8,5 & 13 & 2,5 \\
\hline & 4 & 17,5 & 9,5 & 4,5 \\
\hline & 5 & 8,5 & 3,5 & 2,5 \\
\hline Rata-rata & & 9,7 & 7,4 & 3,1 \\
\hline
\end{tabular}

- Diameter zona hambat $>2 \mathrm{~mm}$ dinyatakan sampel positif mengandung residu antibiotik

- Diameter zona hambat <13mm batas maksimum residu berdasarkan aturan SNI No. 01 -6366-2000

Tabel 2 memperlihatkan bahwa dari 15 sampel daging ayam broiler yang berasal dari 3 pasar tradisional yaitu pasar Kota, Mandonga dan Bonggoea, semua sampel positif mengandung residu antibiotik golongan makrolida. Hasil penelitian ini membuktikan bahwa masih tingginya penggunaan antibiotik golongan makrolida pada peternakan ayam broiler dan utamanya diberikan untuk pengobatan penyakit saluran pernapasan yang menyebabkan angka kematian yang tinggi untuk ayam broiler. Antibiotik makrolida biasanya ditambahkan pada air minum ayam sebagai pencegah penyakit pernapasan.

Delepine et al., (1996) melaporkan bahwa antibiotika golongan makrolida dipakai secara luas dalam industri peternakan yang umumnya dipergunakan untuk pengobatan penyakit pernafasan disamping ditambahkan dalam campuran makanan sebagai perangsang pertumbuhan (growth promotor).

Rataan diameter zona hambat sampel daging ayam berasal dari pasar Kota yakni 9,7 mm, pasar Mandonga 7,4 $\mathrm{mm}$ dan pasar Bonggoea 3,1 mm masih di bawah Batas Maksimum Residu yang ditetapkan SNI No. 01 - 6366 - 2000 yaitu maksimal 0,1 ppm (diameter zona hambat $<13 \mathrm{~mm}$ ) sehingga masih aman dikonsumsi.

Menurut Yuningsih et al., (2005) hasil analisis residu antibiotik golongan makrolida terhadap sampel lapang daerah Sukabumi, Bogor dan Tangerang menunjukkan 15 dari 36 sampel positif 
mengandung residu golongan makrolida yang masih di bawah ambang batas yang diperbolehkan dan sampel lainnya negatif. Hal ini sejalan dengan hasil penelitian yang menunjukkan bahwa meskipun semua sampel positif mengandung residu antibiotik golongan makrolida namun residu tersebut masih dalam ambang batas SNI No. 01 - 6366 - 2000 dan masih aman untuk dikonsumsi.

Pemberian antibiotik pada peternakan ayam erat kaitannya dengan kondisi musim yang tidak stabil dan memungkinkan ayam lebih mudah terserang penyakit, sehingga antibiotik diberikan untuk pencegahan maupun pengobatan penyakit. Menurut Distannak (2005) tingginya angka sakit dan kematian pada unggas baik ayam petelur maupun pedaging mengakibatkan peternak mengupayakan mengobati ternaknya dengan menggunakan antibiotika. Namun akibat penggunaan antibiotika yang tidak rasional (diagnosa yang belum jelas) dan untuk mengurangi kerugian yang lebih besar peternak menjual ternaknya walaupun masih dalam masa pengobatan. Waktu henti obat yang seharusnya dilewati, di abaikan sehingga residu obat masih terdapat pada tubuh ternak saat dipotong.

Hasil pengujian antibiotik makrolida juga menemukan 1 sampel dari pasar Kota yang sudah tidak aman dikonsumsi menurut SNI No.01 - 6366 2000, hal ini kemungkinan ternak yang dipotong masih dalam keadaan sakit (dalam masa pengobatan) atau sudah sembuh tetapi waktu henti obat (withdrawaltime) belum berakhir sehingga masih terpapar residu antibiotik dalam daging.

\section{Deteksi Residu Antibiotik Golongan Aminoglikosida}

Hasil deteksi residu antibiotik golongan Aminoglikosida daging ayam broiler yang beredar di pasar tradisional Kota Kendari dapat dilihat pada Tabel 3 berikut.

Tabel 3. Rataan Diameter Zona Hambat Pengujian Residu Antibiotik golongan Aminoglikosida pada Daging Ayam Broiler

\begin{tabular}{|c|c|c|c|c|}
\hline \multirow{2}{*}{ Jenis Antibiotik } & \multirow{2}{*}{ Sampel } & \multicolumn{3}{|c|}{ Lokasi } \\
\hline & & Pasar Kota & Pasar Mandonga & Pasar Bonggoeya \\
\hline & & & $\ldots \ldots \ldots(\mathrm{mm}) \ldots \ldots$ & 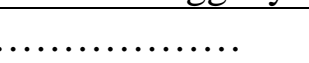 \\
\hline \multirow{5}{*}{ Aminoglikosida } & 1 & 10,5 & 0 & 0 \\
\hline & 2 & 7,0 & 0 & 6,0 \\
\hline & 3 & 7,5 & 0 & 8,5 \\
\hline & 4 & 12,0 & 0 & 4,5 \\
\hline & 5 & 7,5 & 0 & 7,5 \\
\hline Rata-rata & & 8,9 & 0 & 5,3 \\
\hline
\end{tabular}

Tabel 3 memperlihatkan bahwa dari 15 sampel daging ayam broiler yang berasal dari 3 pasar tradisional, 10 sampel positif mengandung residu antibiotik golongan aminoglikosida yaitu berasal dari pasar Kota dan Bonggoea, sedangkan pasar Mandonga tidak terdapat satupun sampel yang positif mengandung residu antibiotik aminoglikosida. Rataan diameter zona hambat sampel daging ayam berasal dari pasar Kota yakni 9,7 mm, pasar Mandonga negatif dan pasar Bonggoea 5,3 $\mathrm{mm}$ masih dibawah Batas Maksimum Residu yang ditetapkan SNI No. 01 - 6366 - 2000 yaitu maksimal 0,1 ppm (diameter zona hambat $<13 \mathrm{~mm}$ ) sehingga masih aman dikonsumsi. 
Menurut Yuningsih et al., (2005) masih tingginya angka sampel yang positif mengandung residu antibiotik menunjukkan bahwa antibiotik jenis ini masih digunakan pada peternakan ayam broiler karena antibiotik golongan aminoglikosida umumnya digunakan untuk obat pernapasan pada ayam.

Selain itu, aminoglikosida memiliki spektrum luas dan bersifat bakterisidal (membunuh bakteri) dengan mekanisme penghambatan pada sintesis protein. Antibiotik ini menghambat bakteri agar tidak mampu mensintesis protein vital untuk pertumbuhannya dan merupakan obat yang umum digunakan untuk pengobatan pada ayam (Pratiwi, 2008).

Pemakaian antibiotika tidak beraturan atau tidak tepat dosis atau tidak sesuai dengan diagnosa penyakitnya dapat menyebabkan residu dalam jaringanjaringan atau organ ternak yang cukup berbahaya bagi kesehatan manusia yang mengkonsumsinya, yaitu dapat menyebabkan reaksi alergi atau resistensi dan kemungkinan menyebabkan keracunan (Yuningsih et al., 2005).

\section{KESIMPULAN}

Berdasarkan hasil analisa dan pembahasan dapat disimpulkan bahwa terdapat residu antibiotik golongan tetrasiklin, makrolida, dan aminoglikosida dalam daging ayam broiler yang beredar di pasar tradisional Kota Kendari, namun masih berada dibawah batas maksimum Standar Nasional Indonesia (SNI) dan masih aman untuk dikonsumsi.

1. Untuk mengurangi residu antibiotik dalam daging perlu dilakukan pengolahan yang baik sebelum dikonsumsi sehingga dapat menurunkan kadar antibiotik dalam daging.

2. Perlu dilakukan penelitian lebih lanjut mengenai residu antibiotik dalam daging ayam broiler baik yang berasal dari Makasar maupun yang berasal dari Kota Kendari.

\section{DAFTAR PUSTAKA}

Adam, R., 2002. Veterinary pharmacology and therapeutics. IOWA State University Press/Ames. USA.

Anief, M., 1993. Farmasetika. Gadjah Mada University Press. Yogyakarta.

Anthony, T., 1997. Food poisoning. Departement of Biochemistry Colorado Estate University. New york

Anonimous, $1994 . \quad$ Hati-hati menggunakan feed additive. Infovet. Edisi 014 Mei-Juni.

Anonimous, 2008. Antibiotik. Gadjah Mada University Press. Yogyakarta.

Anonimous, 2010. Taati Aturan Pakai untuk Kerja Obat Optimal.(http://info.medion. co.id/index.php/artikel/layer/pengo batan- a - vaksinasi/review antibiotik) [28 Maret 2012]

Bahri, S., 2008. Beberapa Aspek Keamanan Pangan Asal Ternak di Indonesia. Pengembangan Inovasi Pertanian 1(III).

Botsoglou, N.A., D.J. Fletouris, 2001. Drug Residues in Foods pharmacology, Food Safety, and Analysis. New York: Marcel Dekker.

Butaye P., A. Devriese, F. Haesebrouck, 2003. Antimicrobial growth promotors used in animal feed: effect of less well known antibiotiks on gram-positive Bacteria. Clinical Microbiology Reviews.

Dewi, A.A., N. M. Handayani, 2002. Survei Residu Antibiotika pada produk asal hewan di Kabupaten Badung. Jurnal Balai Penyidikan dan Pengujian Veteriner Regional VI Denpasar.

Delepine, B., D.H. Pessel and P. Sanders, 1996. Multiresidue Method for 
Confirmation of Macrolide Abtibiotics in BovineMuscle by Liquid Chromatography/ Mass Spectrometry. J. AOAC.

Dinas Pertanian Sulawesi Tenggara, 2010. Statistik peternakan 2005-2009. Kendari, Pemerintah Provinsi Sulawesi Tenggara.

Dinas Peternakan Sulawesi Selatan, 2011. Pemanfaatan antibiotik dan zat aditif dalam pakan ternak. (http://disnaksulsel.info) [3 September 2011].

Focosi, D., 2005. Antimicrobial for bacteria(http://focosi.altervista.org/) [2 September 2011]

Handayani, N. M., A.A. Dewi, 2003. Survei cemaran mikroba dan residu antibiotika dan sulfa pada produk asal hewan di provinsi Nusa Tenggara Barat dan Nusa Tenggara Timur tahun 2003. Jurnal Balai Penyidikan dan Pengujian Veteriner Regional VI. Denpasar.

Infovet, 2007. Peran obat hewan dalam keamanan produk ternak. (http://www. majalahinfovet.com/2007/10/peran -obat-hewan-dalam-keamananproduk. html). [25 Agustus 2011].

Keirs. R. W., E. D. Peebles, S. A. Hubbard, and S. K. Whitmarsh, 2002. Effect of supportive gluconeogenic substance on the early performance of broiler under adequate brooding conditions. College of Veterinary Medicine and Poultry Science.

Martaleni, 2007. Deteksi residu antibiotika pada karkas, organ dan kaki ayam pedaging yang diperoleh dari pasar tradisional kota Tangerang. Tesis. IPB. Bogor.

Muchtadi, T.R., Sugiono, 1992. Petunjuk laboratorium ilmu pengetahuan badan pangan. Kerjasama Dirjen Dikti Depdiknas dengan PAU. IPB. Bogor.

Murdiati, T.B., S. Bahri, 1991. Pola penggunaan antibiotika dalam peternakan ayam diJawa Barat, kemungkinan hubungan dengan masalah residu. Proceedings Kongres llmiah ke 8 /SFI, Jakarta.

Murtidjo, 2008. Beternak ayam Broiler. Edisi revisi. Kanisius. Yogyakarta.

Pratiwi, T., 2008. Mikrobiologi farmasi. Erlangga, Jakarta.

Soeparno, 2009. Ilmu dan teknologi daging. Gadjah mada University Press. Yogyakarta.

Standar Nasional Indonesia, 2000. SNI No. : 01 - 6366-2000. Batas maksimum cemaran mikroba dan residu maksimum antibiotik dalam bahan makanan asal hewan.(http://pphp.deptan.go.id/xpl ore/view.php?file=MUTUSTANDARISASI/STANDARMUTU/Standar_nasional/SNITerna k /Metode\%20Uji /1.pdf) [13 September 2011]

Subronto, I. Tjahajati, 2008. Ilmu penyakit ternak III: Farmakologi Veteriner, Farmakodinamika dan Farmakokinesis, Farmakologi Klinis. Gadjah Mada University Press. Yogyakarta.

Suhari, H., 1997. Antibiotika untuk Pertumbuhan Ternak. Infovet Edisi 049 Agustus 1997. 
Winarno, F.G., 1996. Undang-undang tentang pangan. Kumpulan Makalah pada Musyawarah II dan Seminar Ilmiah Persatuan Ahli Teknologi Laboratorium Kesehatan Indonesia. Jakarta, 25-26 November 1996.

Wattimena, J. R., 1991. Farmakodinami dan terapi antibiotik. Gadja Mada University Press. Yogyakarta.
Yuningsih, T. B. Murdiati, S. Juariah, 2005. Keberadaan residu antibiotik Tilosin (Golongan Makrolida) dalam daging ayam daerah Sukabumi, Bogor dan Tangerang. Balai Penelitian Veteriner Bogor. 